\title{
Carbon stable isotope discrimination during respiration in three seaweed species
}

\author{
Matheus C. Carvalho*, Bradley D. Eyre \\ Centre for Coastal Biogeochemistry Research, School of Environmental Science and Management, \\ Southern Cross University, PO Box 157, Lismore, New South Wales, Australia
}

\begin{abstract}
Very little is known about seaweed stable carbon isotope discrimination during respiration $\left(\Delta_{\mathrm{r}}\right.$, defined here as the difference between respired $\mathrm{CO}_{2} \delta^{13} \mathrm{C}$ and algal tissue $\left.\delta^{13} \mathrm{C}\right)$. However, $\Delta_{\mathrm{r}}$ can give information on carbon metabolic pathways in seaweeds, and can also be helpful to better understand their role in carbon cycling. Here we measured the $\Delta_{\mathrm{r}}$ of Ulva sp. (Chlorophyta), Pterocladia capillacea Bornet (Rhodophyta) and Sargassum sp. (Ochrophyta) under 3 different experimental conditions: at 15 and $25^{\circ} \mathrm{C}$ after strong illumination for 30 to $60 \mathrm{~min}$, and at $25^{\circ} \mathrm{C}$ after at least $20 \mathrm{~h}$ in the dark. We observed a correlation between $\Delta_{\mathrm{r}}$ and the respiratory quotient $\left(\mathrm{RQ}\right.$, defined as the ratio between $\mathrm{CO}_{2}$ release and $\mathrm{O}_{2}$ consumption), suggesting changes in the organic substrate used for respiration in the different treatments. $\Delta_{\mathrm{r}}$ was positive in most cases, suggesting that carbohydrates were the likely substrate for respiration; however, $\Delta_{\mathrm{r}}$ (and the RQ) decreased with an increase in temperature, suggesting increased use of lipids as substrates. Although $\Delta_{\mathrm{r}}$ was not large (averaging $3 \%$ ), the influence of seaweed respiration on the $\delta^{13} \mathrm{C}$ of dissolved inorganic carbon may need to be taken into account in ecosystems where seaweeds dominate primary production (i.e. eutrophic lagoons). $\Delta_{\mathrm{r}}$ may also be important when interpreting seaweed $\delta^{13} \mathrm{C}$ values to determine the form of inorganic carbon used in photosynthesis.
\end{abstract}

KEY WORDS: ${ }^{13} \mathrm{C}$ - Fractionation - Macroalgae - Respiration - Respiratory quotient · Short-term incubation

Resale or republication not permitted without written consent of the publisher

\section{INTRODUCTION}

The stable carbon isotope composition $\left(\delta^{13} \mathrm{C}\right)$ of aquatic primary producers has been measured in many studies as it allows identification of the energy sources of consumers in the food web. The $\delta^{13} \mathrm{C}$ of the different possible food sources in food web studies need to have distinct values (signatures) with little variability to separate the sources. However, the $\delta^{13} \mathrm{C}$ in seaweeds can show wide variation over limited spatial scales (Stephenson et al. 1984, Fenton \& Ritz 1989), and most of this variation has been hard to explain. This variation is typically dealt with by undertaking large amounts of sampling of seaweeds through time and space (Fredriksen 2003, Won et al. 2007). Finally, seaweed $\delta^{13} \mathrm{C}$ can be used to infer the chemical form of inorganic carbon $\left(\mathrm{CO}_{2}\right.$ or $\left.\mathrm{HCO}_{3}{ }^{-}\right)$ taken up in photosynthesis, which can help to explain their distribution in nature (Maberly et al. 1992).

Incubations in the laboratory (Wiencke \& Fischer 1990, Carvalho et al. 2009b, 2010) and in the field (Carvalho et al. 2009a) have shown that conditions that favor higher photosynthetic or growth rates usually result in seaweeds with higher $\delta^{13} \mathrm{C}$. Other studies have proposed that environmental factors like water velocity could be the cause for the observed variation (Raven et al. 1982, Raven et al. 1994). In all cases, the observed variability has been explained by variation in ${ }^{13} \mathrm{C}$ discrimination in photosynthesis $\left(\Delta_{\mathrm{p}}\right)$. However, respiratory losses in seaweeds amount on average to $\sim 55 \%$ of gross photosynthesis (Duarte \& Cebrian 1996, Middelburg et al. 2005); thus, discrimination during respiration $\left(\Delta_{\mathrm{r}}\right.$, defined here as differance between the $\delta^{13} \mathrm{C}$ of respired $\mathrm{CO}_{2}$ and that in 
the bulk algal tissue) influence on the overall organism $\delta^{13} \mathrm{C}$ can be important.

Aquatic respiration is typically dominated by microbial respiration (Del Giorgio \& Williams 2005), including respiration of seaweed detritus. However, respiration by seaweeds comprises the bulk of the respiration in some coastal communities (Middelburg et al. 2005), which means that $\mathrm{CO}_{2}$ respired by seaweeds may influence the $\delta^{13} \mathrm{C}$ of dissolved inorganic carbon in nearby waters, especially in rocky tidal pools during low tide.

In terrestrial plants, there has been a growing recognition that not only $\Delta_{\mathrm{p}}$, but also $\Delta_{\mathrm{r}}$, can shape plant $\delta^{13} \mathrm{C}$ (Ghashghaie et al. 2003, Pataki 2005, Tcherkez et al. 2010), although this has largely been ignored in aquatic plants. It is unknown if the patterns found for $\Delta_{\mathrm{r}}$ in land plants are also observed in algae; thus, studies addressing $\Delta_{\mathrm{r}}$ could enhance understanding of the variation of $\delta^{13} \mathrm{C}$ in algae.

Investigations in land plants have shown that temperature and light exposure affect $\Delta_{\mathrm{r}}$ (Tcherkez et al. 2003, Gessler et al. 2009, Werner et al. 2009). An increase in temperature can cause an increased rate of lipid consumption, which is reflected in $\Delta_{\mathrm{r}}$ (Tcherkez et al. 2003). Light exposure inhibits part of the Krebs cycle, leading to the accumulation of metabolites which are preferentially consumed in the first minutes of darkness, a process that influences $\Delta_{\mathrm{r}}$ (Tcherkez et al. 2003, Gessler et al. 2009, Werner et al. 2009). Here we measured $\Delta_{\mathrm{r}}$ for 3 species of seaweeds under different experimental conditions. Our hypothesis was that temperature and light exposure before darkness would affect $\Delta_{\mathrm{r}}$, similar to the effect in land plants. We also measured the respiratory quotient $(R Q$, defined as the amount of $\mathrm{CO}_{2}$ released divided by the amount of $\mathrm{O}_{2}$ consumed in respiration) because it has helped explain patterns of $\Delta_{\mathrm{r}}$ in higher plants (Tcherkez et al. 2003, Barbour et al. 2007, Gessler et al. 2009). The implications of the findings for the role of seaweeds in the carbon cycle of ecosystems and the application of tissue $\delta^{13} \mathrm{C}$ in determining the form of inorganic carbon used in photosynthesis are discussed.

\section{MATERIALS AND METHODS}

\section{Main experiments}

Ulva sp. (Chlorophyta), Pterocladia capillacea Bornet (Rhodophyta) and Sargassum sp. (Ochrophyta), which are among the most abundant seaweeds at the rocky section of Shelly Beach in Ballina, NSW, Aus- tralia $\left(28^{\circ} 51^{\prime} 53^{\prime \prime} \mathrm{S}, 153^{\circ} 35^{\prime} 37^{\prime \prime} \mathrm{E}\right)$, were collected at low tide. The algae were transported to the laboratory in the dark, and kept for 1 to $3 \mathrm{~d}$ in aerated seawater with a $12 \mathrm{~h}$ photoperiod at low irradiance $\left(\sim 40 \mu \mathrm{mol} \mathrm{m} \mathrm{m}^{-2} \mathrm{~s}^{-1}\right)$ from fluorescent lamps and at $\sim 22^{\circ} \mathrm{C}$ until the start of experiments. One day before the experiment for a given species, several thalli of the chosen species were transferred to other aquaria and kept overnight in aerated seawater in the dark at 15 or $25^{\circ} \mathrm{C}$. These temperatures are within the limits of variation of sea surface temperature in the area where the specimens were collected (BoM 2011).

For each species, 3 different treatments were employed: incubations at 15 and $25^{\circ} \mathrm{C}$ after 30 to $60 \mathrm{~min}$ of strong illumination using a 400W lamp (Philips Son T Agro, $400 \mu \mathrm{mol} \mathrm{m} \mathrm{m}^{-2} \mathrm{~s}^{-1}$ ), and incubations at $25^{\circ} \mathrm{C}$ after at least $20 \mathrm{~h}$ in the dark. Each treatment was replicated 5 to 7 times for each species. Incubation chambers were transparent plastic terumo syringe barrels $(60 \mathrm{ml})$ covered with aluminum foil. For each syringe used, the rubber gasket was removed from the plunger and cut with a knife in its middle, and after that affixed to the probe of an optical dissolved oxygen $\left(\mathrm{O}_{2}\right)$ sensor (Hach LDO, connected to Hach HQ40d). A tygon tube was affixed to the needle connector of the barrel and closed with a clip. A magnetic stir bar was placed inside the chamber to ensure water mixing. To determine whether the setup was leak free, a mounted chamber was left outside of the water and observed for leaks, or for bubbles.

Just before starting the incubations, the thalli were tied to the $\mathrm{O}_{2}$ probe with plastic nylon wire, taking care not to damage the thalli. The amount of algal tissue used in each incubation was estimated based on previous trials so as to give a measurable change in dissolved inorganic carbon (DIC) concentration ([DIC]) after $1 \mathrm{~h}$ of incubation. To enhance the change in DIC $\delta^{13} \mathrm{C}$ due to respiration, drops of concentrated $\mathrm{HCl}$ were added to filtered $(0.45 \mu \mathrm{m})$ site seawater that was stored refrigerated at $4^{\circ} \mathrm{C}$ to reduce [DIC] until a pH of $\sim 7.5$ was attained $1 \mathrm{~d}$ before the experiments; the water was then left aerated at 15 or $25^{\circ} \mathrm{C}$. The thalli were washed in this medium just before the incubation, and then the incubation chamber was filled with the medium, and subsequently closed with the $\mathrm{O}_{2}$ probe attached to the syringe gasket and holding the thalli. Bubbles were removed by shaking and refilling the syringe several times, then $\sim 23 \mathrm{ml}$ of water was sampled to completely fill a soft-cap vial that was immediately capped and stored in a refrigerator. This water was used for [DIC] and DIC $\delta^{13} \mathrm{C}$ measurements. No preservative was added because water samples had 
been previously filtered, and measurements were done within 12 to $24 \mathrm{~h}$ after sampling. $\mathrm{O}_{2}$ concentrations were monitored and the incubations were terminated after a minimum decrease of $2 \mathrm{mg} \mathrm{O}_{2} \mathrm{l}^{-1}$ was recorded. At this point, $23 \mathrm{ml}$ of the water in the incubation chamber was taken for [DIC] and DIC $\delta^{13} \mathrm{C}$ analysis. Each replication was done using different thalli. The thalli used for a given incubation were washed with tap water and dried at $60^{\circ} \mathrm{C}$ until constant weight. These samples were then kept in a desiccator until $\delta^{13} \mathrm{C}$ was measured. The $\delta^{13} \mathrm{C}$ and carbon content as a percentage of dry weight $(\% \mathrm{C})$ of plant samples were measured using an elemental analyzer (Flash EA, Thermo Fisher) coupled to an isotope ratio mass spectrometer (IRMS; Delta V plus, Thermo Fisher). [DIC] and DIC $\delta^{13} \mathrm{C}$ measurements were done using a TIC/TOC analyzer (Aurora 1030, OI Analytical) coupled to the IRMS (Oakes et al. 2010). Nutrients in the acidified seawater used for incubations $\left(\mathrm{NO}_{3}{ }^{-}, \mathrm{NH}_{4}{ }^{+}\right.$and $\left.\mathrm{PO}_{4}{ }^{3-}\right)$ were measured using a Flow inject analysis system (QuickChem 8500 series 2) (see Eyre \& Ferguson 2005 for details of the method), and $\mathrm{pH}$ was measured using a $\mathrm{pH}$ meter (Hach HQ40d).

\section{pH effect experiment}

Because the $\mathrm{pH}$ during incubations was lower than in ordinary seawater, an experiment was done to determine if this could have affected algal physiology and the respiratory response. Extra incubations for the 3 species were done in the dark at $\mathrm{pH} 7.55$ and 8.20 , at $20^{\circ} \mathrm{C}$, following $12 \mathrm{~h}$ under weak illumination $\left(\sim 40 \mu \mathrm{mol} \mathrm{m} \mathrm{m}^{-2} \mathrm{~s}^{-1}\right)$. In these incubations (3 replications species ${ }^{-1}$ treatment $^{-1}$ ), only the change in $\mathrm{O}_{2}$ was measured.

\section{Calculations and statistics}

Respiratory rates were based on total algal carbon in each chamber (obtained by multiplying plant \%C by its dry weight). The change in [DIC] over time was multiplied by the chamber volume, which was measured by subtracting probe, stirrer and plant volumes from the total volume. In the $\mathrm{pH}$ effect experiment, only rates of $\mathrm{O}_{2}$ consumption per unit time were calculated using the dry weight of the algae.

The temperature effect was tested between the 2 treatments after illumination using a Student $t$-test. A similar test was done between the 2 treatments at $25^{\circ} \mathrm{C}$ to test the illumination effect. We did not directly compare the $15^{\circ} \mathrm{C}$ treatment and the $25^{\circ} \mathrm{C}$ dark treatment due to the possibility of confounding factors. We also did not test differences between species because this was not an objective of the study. Student $t$-tests were also done to compare RQ means with $1, \Delta_{\mathrm{r}}$ means with 0 , and the parameters of regression lines between RQ and $\Delta_{\mathrm{r}}$ with 0 . All tests were conducted using the software Kyplot (Kyenslab, Japan) at the $5 \%$ significance level.

\section{RESULTS}

Incubation conditions for the 3 species were fairly uniform (Table 1), with a salinity of $35, \mathrm{pH}$ of $\sim 7.5$, and low nutrient concentrations, with slightly higher values for the water used for Sargassum sp. incubations.

In all incubations, there was a decrease in $\mathrm{O}_{2}$ (ranging between 2 and $7 \mathrm{mg} \mathrm{l}^{-1}$ ), and an increase in [DIC] (ranging between 0.06 and $0.21 \mathrm{mmol} \mathrm{l}^{-1}$ ) (Table 2). DIC $\delta^{13} \mathrm{C}$ typically decreased by 1 to $4 \%$, but increased in some incubations for Ulva sp. by up to $1 \%$. Initial $\mathrm{O}_{2}$ was higher for incubations at $15^{\circ} \mathrm{C}$, reflecting higher $\mathrm{O}_{2}$ solubility at lower temperatures.

The $\delta^{13} \mathrm{C}$ of plant tissue varied between -10.1 and $-14.2 \%$ for Ulva sp., -13.5 and $-16.7 \%$ for Pterocladia capillacea, and -10.0 and $-16.3 \%$ for Sargassum sp. (Table 2, Appendix 1). Organic carbon content (\% C) was similar (25 to $31 \%$ of dry weight) for Ulva sp. and Sargassum sp., but was higher for P. capillacea (28 to $37 \%$ ).

$\mathrm{pH}$ did not significantly affect $\mathrm{O}_{2}$ consumption rates in any species (Table 3 ). Temperature significantly affected $\mathrm{O}_{2}$ consumption rates, with a $50 \%$ reduction at $15^{\circ} \mathrm{C}$ compared to $25^{\circ} \mathrm{C}$ for all species ( $p<0.01$; Fig. 1a). Light exposure, however, significantly affected $\mathrm{O}_{2}$ consumption only for Pterocladia capillacea ( $\mathrm{p}<0.001$; Fig. 1a). Independent of treatment, Ulva sp. had much higher $\mathrm{O}_{2}$ consumption rates (between 1 and $2.2 \mathrm{mmol} \mathrm{O}_{2} \mathrm{~h}^{-1} \mathrm{~mol} \mathrm{C}^{-1}$ ) than the other 2 species (between 0.4 and $0.8 \mathrm{mmol} \mathrm{O}_{2} \mathrm{~h}^{-1}$ mol C ${ }^{-1}$ ).

$\mathrm{CO}_{2}$ release rates by Ulva sp. and Pterocladia capillacea were significantly affected by temperature $(\mathrm{p}<$

Table 1. Chemical properties of incubation water. Concentrations in $\mu \mathrm{M}$

\begin{tabular}{|lccccc|}
\hline & Salinity & $\mathrm{pH}$ & {$\left[\mathrm{NO}_{3}\right]$} & {$\left[\mathrm{NH}_{4}\right]$} & {$\left[\mathrm{PO}_{4}\right]$} \\
\hline Ulva sp. & 35 & 7.35 & 1.2 & 2.1 & 1.0 \\
Pterocladia capillacea & 35 & 7.60 & 1.2 & 2.1 & 1.0 \\
Sargassum sp. & 35 & 7.70 & 2.6 & 2.1 & 1.6 \\
\hline
\end{tabular}


Table 2. Means $( \pm \mathrm{SD})$ of incubation results. $\mathrm{O}_{2}$ : dissolved oxygen concentration $\left(\mathrm{mg} \mathrm{l}^{-1}\right)$; [DIC]: dissolved inorganic carbon concentration $\left(\mathrm{mmol} \mathrm{l}^{-1}\right) ; \delta^{13} \mathrm{C}$ : stable carbon isotope composition $(\%)$; DW: dry weight $(\mathrm{g})$ of the alga used in the incubation;

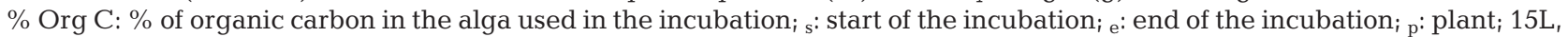
25L and 25D: refer to Fig. 1. See Appendix 1 for a full list of individual values for each incubation

\begin{tabular}{|c|c|c|c|c|c|c|c|c|c|}
\hline & $\mathrm{O}_{2 \mathrm{~s}}$ & $\mathrm{O}_{2 \mathrm{e}}$ & {$[\mathrm{DIC}]_{\mathrm{s}}$} & {$[\mathrm{DIC}]_{\mathrm{e}}$} & $\delta^{13} \mathrm{C}_{\mathrm{s}}$ & $\delta^{13} \mathrm{C}_{\mathrm{e}}$ & DW & $\%$ Org C & $\delta^{13} \mathrm{C}_{\mathrm{p}}$ \\
\hline \multicolumn{10}{|c|}{ Ulva sp. } \\
\hline $15 \mathrm{~L}$ & $9.49 \pm 0.07$ & $4.74 \pm 1.50$ & $0.18 \pm 0.00$ & $0.31 \pm 0.02$ & $-6.2 \pm 0.8$ & $-6.4 \pm 1.1$ & $0.224 \pm 0.077$ & $30.1 \pm 1.6$ & $-12.6 \pm 1.2$ \\
\hline $25 \mathrm{~L}$ & $8.21 \pm 0.19$ & $2.60 \pm 0.52$ & $0.18 \pm 0.01$ & $0.30 \pm 0.01$ & $-7.6 \pm 0.7$ & $-7.9 \pm 0.8$ & $0.142 \pm 0.046$ & $30.0 \pm 1.4$ & $-12.1 \pm 1.0$ \\
\hline $25 \mathrm{D}$ & $8.47 \pm 0.43$ & $3.05 \pm 0.55$ & $0.21 \pm 0.02$ & $0.32 \pm 0.03$ & $-5.2 \pm 1.4$ & $-7.7 \pm 0.5$ & $0.149 \pm 0.032$ & $28.4 \pm 2.4$ & $-12.0 \pm 1.5$ \\
\hline \multicolumn{10}{|c|}{ Pterocladia capillacea } \\
\hline $15 \mathrm{~L}$ & $9.64 \pm 0.05$ & $6.95 \pm 0.40$ & $0.40 \pm 0.01$ & $0.50 \pm 0.03$ & $0.4 \pm 0.6$ & $-1.8 \pm 0.8$ & $0.204 \pm 0.051$ & $35.3 \pm 1.2$ & $-14.5 \pm 0.7$ \\
\hline $25 \mathrm{~L}$ & $8.52 \pm 0.08$ & $4.27 \pm 1.11$ & $0.39 \pm 0.01$ & $0.50 \pm 0.05$ & $-0.2 \pm 0.5$ & $-3.1 \pm 0.9$ & $0.171 \pm 0.067$ & $33.4 \pm 3.3$ & $-15.4 \pm 0.4$ \\
\hline $25 \mathrm{D}$ & $8.36 \pm 0.11$ & $3.35 \pm 1.08$ & $0.39 \pm 0.01$ & $0.52 \pm 0.03$ & $-1.1 \pm 0.3$ & $-3.9 \pm 0.5$ & $0.264 \pm 0.058$ & $35.6 \pm 0.9$ & $-15.5 \pm 0.7$ \\
\hline \multicolumn{10}{|c|}{ Sargassum sp. } \\
\hline $15 \mathrm{~L}$ & $9.58 \pm 0.11$ & $6.41 \pm 1.03$ & $0.53 \pm 0.02$ & $0.64 \pm 0.03$ & $3.4 \pm 1.1$ & $1.6 \pm 1.4$ & $0.241 \pm 0.070$ & $29.1 \pm 1.4$ & $-12.8 \pm 2.4$ \\
\hline $25 \mathrm{~L}$ & $8.49 \pm 0.03$ & $4.09 \pm 0.10$ & $0.55 \pm 0.01$ & $0.64 \pm 0.01$ & $1.4 \pm 0.7$ & $-0.5 \pm 0.6$ & $0.205 \pm 0.080$ & $28.7 \pm 1.5$ & $-13.5 \pm 1.2$ \\
\hline $25 \mathrm{D}$ & $8.43 \pm 0.14$ & $4.62 \pm 0.60$ & $0.54 \pm 0.01$ & $0.61 \pm 0.01$ & $1.0 \pm 0.2$ & $-0.5 \pm 0.2$ & $0.236 \pm 0.052$ & $27.4 \pm 1.9$ & $-12.1 \pm 1.8$ \\
\hline
\end{tabular}

Table 3. Respiration rates $\left(\mathrm{mg} \mathrm{O}_{2} \mathrm{mg} \mathrm{DW}^{-1} \mathrm{~h}^{-1}\right.$ ) for the $\mathrm{pH}$ experiment. $\mathrm{p}$-values are for non-paired Student $t$-test for difference of means $(n=3)$

\begin{tabular}{|lccc|}
\hline & $\mathrm{pH}=7.55$ & $\mathrm{pH}=8.20$ & $\mathrm{p}$ \\
\hline Ulva sp. & $0.42 \pm 0.15$ & $0.57 \pm 0.10$ & 0.24 \\
Pterocladia capillacea & $0.33 \pm 0.00$ & $0.37 \pm 0.02$ & 0.05 \\
Sargassum sp. & $0.47 \pm 0.19$ & $0.52 \pm 0.04$ & 0.69 \\
\hline
\end{tabular}

0.05; Fig. 1b), with Ulva sp. releasing $\sim 50 \%$ less $\mathrm{CO}_{2}$ at $15^{\circ} \mathrm{C}$ than at $25^{\circ} \mathrm{C}$. Similar to $\mathrm{O}_{2}$ consumption rates, $\mathrm{CO}_{2}$ release rates were significantly affected by light exposure only for P. capillacea ( $\mathrm{p}<0.01)$.

RQ were similar among species, with averages between 0.6 and 1.2 (Fig. 1c). Average RQ values at $15^{\circ} \mathrm{C}$ were not significantly different from 1 (the commonly expected value, Falkowski \& Raven 2007) for any species. However, RQ values at $25^{\circ} \mathrm{C}$ were significantly different from $1(p<0.05)$ in all other treatments except after light exposure for Pterocladia capillacea. Light exposure did not influence average $R Q$, with no significant difference between the light and dark exposed treatments at $25^{\circ} \mathrm{C}$ for any species. Temperature, however, affected RQ in P. capillacea and in Sargassum sp., with higher values at $15^{\circ} \mathrm{C}$. Values also tended to be higher at $15^{\circ} \mathrm{C}$ in Ulva sp., but this was not significant due to high variability.

Average values for $\Delta_{\mathrm{r}}$ were between -1 and $6 \%$ for Ulva sp. and Sargassum sp., but less variable (2 to $4 \%$ ) for Pterocladia capillacea (Fig. 1d). Average $\Delta_{\mathrm{r}}$ were significantly different from $0 \%$ o $(\mathrm{p}<0.05)$ in all treatments except for Ulva sp. and Sargassum sp. at $25^{\circ} \mathrm{C}$ in the dark, and for $P$. capillacea at $25^{\circ} \mathrm{C}$ after light exposure. The temperature effect was significant only for $P$. capillacea, while the light exposure effect was significant only for Ulva sp. There was a significant correlation between RQ and $\Delta_{\mathrm{r}}$ for the 3 species (Fig. 2). However, except for Sargassum sp., correlations were weak, which implies that RQ could not be used to predict $\Delta_{\mathrm{r}}$, or vice-versa. This was especially clear for low RQ between 0.5 and 1.0, which in all of the examined species could be associated with $\Delta_{\mathrm{r}}$ between -2 and $5 \%$.

\section{DISCUSSION}

\section{Respiration rates}

It has been observed that specific respiration rates (in carbon per unit carbon, as in this study) are usually higher for thinner primary producers (Enríquez et al. 1996, Sand-Jensen \& Nielsen 2004). Ulva has a thinner thallus than the other 2 species, and thus has more active cells per unit of carbon, which is reflected in its higher respiration rates compared to the other species (Fig. 1a,b).

The effect of $\mathrm{pH}$ on respiration rates was not significant (Table 3), which is similar to previous seaweed studies (Dromgoole 1978, Zou \& Gao 2010). As such, although the experiments were done at $\mathrm{pH} 7.5$, they should reflect the respiratory metabolism of seaweeds adapted to normal seawater $\mathrm{pH}$ (8.2).

An approximate doubling in rates with a $10^{\circ} \mathrm{C}$ increase in temperature (Fig. 1a,b) is a common pattern consistent with the enzyme-catalyzed nature of reactions involved in respiration, and follows the 

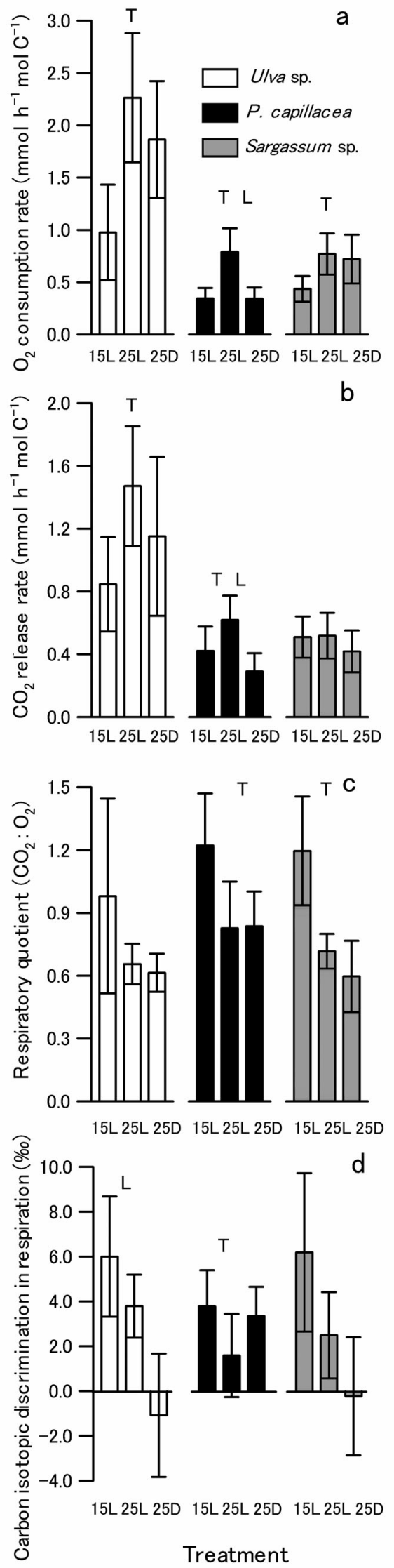

Arrhenius law (Raven \& Geider 1988, Falkowski \& Raven 2007). Enzyme-catalyzed reactions have rates that depend on the rate of intermolecular collisions. Higher temperatures lead to higher random agitation of molecules, which increases the rate of intermolecular collisions, thereby increasing reaction rates (Falkowski \& Raven 2007).

Photosynthesis stimulates $\mathrm{O}_{2}$ consumption in the light, so that immediately after darkness initial rates are relatively high, and then decrease (Falkowski \& Raven 2007). This decrease may be slow and better detected by monitoring $\mathrm{O}_{2}$ consumption at the scale of a few minutes or even seconds in a similar incubation (Falkowski et al. 1985, Weger et al. 1989, Pringault et al. 2007). Natural variation between individuals and perhaps a slow rate of decrease probably prevented us from observing a significant effect of light exposure on average respiration rates in Ulva sp. and Sargassum sp., but not in Pterocladia capillacea (Fig. 1a,b). It is important to highlight that for Pterocladia capillacea, we also observed a decrease in $\mathrm{CO}_{2}$ release rates, which has seldom been measured in algae. The few available data agree with our findings (e.g. Beardall et al. 1994).

\section{Sources of respired $\mathrm{CO}_{2}$}

$\mathrm{RQ}$ and $\Delta_{\mathrm{r}}$ can be used to infer which kind of organic substrate was used in plant respiration (Tcherkez et al. 2003). RQ depends on the oxidation level of the respired substrate, with expected values of $\sim 0.6$ and 1.0 for lipid and carbohydrate oxidation respectively (Ghashghaie et al. 2003). $\Delta_{\mathrm{r}}$ should be lower if lipids are consumed, because lipids have lower $\delta^{13} \mathrm{C}$ than other metabolites in the organism (Park \& Epstein 1961), and it should be higher if carbohydrates are consumed in respiration, because carbohydrates often have higher $\delta^{13} \mathrm{C}$ than the overall value in the organism (Park \& Epstein 1961, Duranceau et al. 1999). Therefore, lipid consumption is indi-

Fig. 1. Results of incubations done in the dark for Ulva sp., Pterocladia capillacea, Sargassum sp. (a) Respiration rates as $\mathrm{O}_{2}$ consumption; (b) respiration rates as $\mathrm{CO}_{2}$ release; (c) respiratory quotients; (d) carbon stable isotope discrimination in respiration. Columns are averages of between 5 and 7 incubations. Error bars indicate standard deviation. Letters over the bars indicate significant statistical difference $(\mathrm{p}>$ 0.05 , Student $t$-test) for temperature (T) or light (L) for a single species. 15L: incubations done at $15^{\circ} \mathrm{C}$ after light exposure for between 30 and $60 \mathrm{~min}$; 25L: incubations done at $25^{\circ} \mathrm{C}$ after light exposure for between 30 and $60 \mathrm{~min}$; 25D: incubations done at $25^{\circ} \mathrm{C}$ without light exposure 


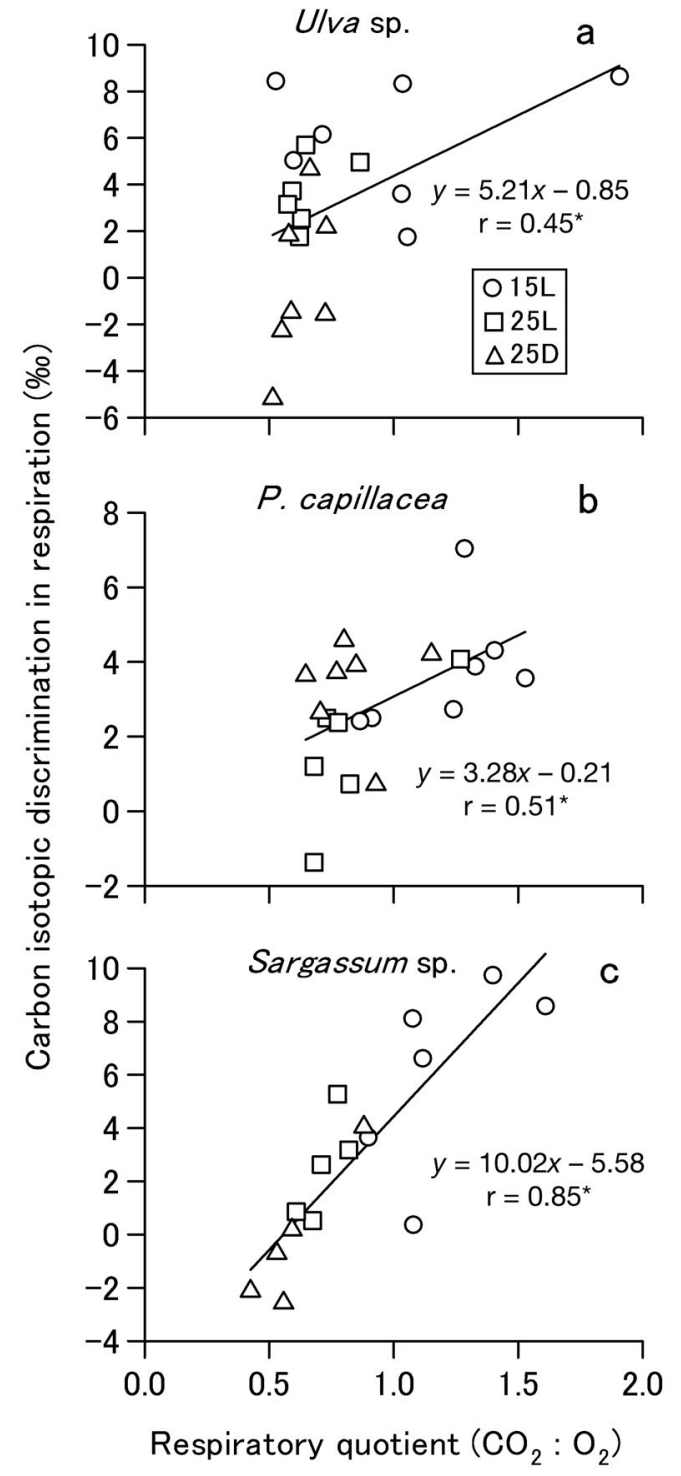

Fig. 2. Relationship between respiratory quotient and carbon stable isotope discrimination in respiration $\left(\Delta_{\mathrm{r}}\right)$ for (a) Ulva sp., (b) Pterocladia capillacea and (c) Sargassum sp. Each symbol represents a single incubation. Continuous lines: linear regression fits of all symbols in a single figure. Equations refer to the regression fits. Asterisks indicate that the regression coefficient is significant $(p<0.05$, Student $t$-test for regression). 15L, 25L and 25D: refer to Fig. 1

cated by both low RQ and $\Delta_{\mathrm{r}}$, while carbohydrate consumption is indicated by the opposite pattern of both high RQ and $\Delta_{\mathrm{r}}$. This was the general trend observed here (Fig. 2), with some exceptions, which might be explained by the consumption of amino acids (Tcherkez et al. 2003), because the $\Delta_{\mathrm{r}}$ from such a consumption would not necessarily follow the defined trend for lipids or carbohydrates. Irrespective of the correspondence between RQ and $\Delta_{\mathrm{r}}$ RQ values were mostly $>1$, and $\Delta_{\mathrm{r}}$ values were mostly posi- tive (Fig. 2), which indicates that carbohydrates were the main substrate of respiration in most cases.

An increase in temperature is expected to lead to a decrease in both RQ and $\Delta_{\mathrm{r}}$ due to an increase in lipid oxidation (Park \& Epstein 1961, Ghashghaie et al. 2003). Results for Pterocladia capillacea were consistent with this expectation, while for Sargassum sp. a significant effect was detected only for $R Q$, and for Ulva sp. it was not observed at all (Fig. 1c,d). Hence, the evidence for increased lipid oxidation with increased temperature was strongest for $P$. capillacea and weakest for Ulva sp.

Light exposure followed by darkness should lead to an increased oxidation of carbohydrates (Werner et al. 2007, Gessler et al. 2009), which should lead to an increase in both RQ and $\Delta_{\mathrm{r}}$. There was a significant effect on $\Delta_{\mathrm{r}}$ in Ulva sp. (Fig. 1d), and $\Delta_{\mathrm{r}}$ in Sargassum sp. had lower values in the 25D than in the $25 \mathrm{~L}$ treatment, except for a single incubation (Fig. 2c). If this outlier is excluded, the effect of light exposure becomes significant. However, the absence of an influence on RQ for the 3 species (Fig. 1c), and the clear absence of an influence on $\Delta_{\mathrm{r}}$ in Pterocladia capillacea (Fig. 1d) indicate that the hypothesized increased consumption of carbohydrates after strong illumination was not demonstrated. The relatively weak evidence for Ulva sp. and Sargassum sp. $\Delta_{\mathrm{r}}$ could suggest that a stronger illumination intensity or longer light exposure might generate the expected effect.

\section{Ecological implications}

DIC $\delta^{13} \mathrm{C}$ in natural waters reflects the interplay of many phenomena occurring simultaneously, like respiration, calcification and aeration (Kroopnick 1985, Zeebe \& Wolf-Gladrow 2001). However, unlike forested terrestrial ecosystems where the carbon respired by plants is a major component of atmospheric $\mathrm{CO}_{2}$ and thus significantly affects its $\delta^{13} \mathrm{C}$ (Bowling et al. 2008), the carbon respired by seaweeds should account for only a minor portion of the DIC in most marine ecosystems because DIC concentration in seawater is much larger than the $\mathrm{CO}_{2}$ concentration in the atmosphere. Regardless of treatment and species, $\Delta_{\mathrm{r}}$ tended to be $>0 \%$, and was only similar to $0 \%$ after prolonged darkness for Ulva sp. and Sargassum sp. (Fig. 1). From an ecosystem perspective, this means that the $\delta^{13} \mathrm{C}$ of carbon respired by seaweeds will often be at least $3 \%$ higher than that measured in the vegetation. This difference is relatively small, and should therefore not significantly alter what is 
presently known about DIC dynamics in most coastal areas. However, in ecosystems where seaweeds are a major portion of the biomass, like some shallow coastal lagoons (Valiela et al. 1997, Eyre \& Maher 2010, Maher \& Eyre in press), this effect might be of more relevance. In other aquatic ecosystems that are less rich in DIC, like many lakes (Bade et al. 2004) and rivers (Finlay 2004), this difference of $3 \%$ between plant and respired $\mathrm{CO}_{2} \delta^{13} \mathrm{C}$ could also be important in understanding DIC dynamics, and consequently the relative importance of respiration by primary producers compared to other potential influencing factors.

Potentially more important than the stable isotope of the respired carbon as a constituent of DIC, the value of $3 \%$ for $\Delta_{\mathrm{r}}$ may influence the interpretation of the $\delta^{13} \mathrm{C}$ values of the organisms themselves. In previous studies, the $\delta^{13} \mathrm{C}$ of a given seaweed has been interpreted as being solely a result of photosynthetic processes (Raven et al. 2002, Carvalho et al. 2009a, Mercado et al. 2009), being used as a direct estimation of $\Delta_{\mathrm{p}}$ (the stable carbon isotope discrimination in photosynthesis). $\Delta_{\mathrm{p}}$ is a useful parameter that allows determination of whether a seaweed uses $\mathrm{HCO}_{3}{ }^{-}$or $\mathrm{CO}_{2}$ in photosynthesis (Maberly et al. 1992, Raven et al. 2002). However, it is possible to estimate $\Delta_{\mathrm{p}}$ using a simple mass balance that also accounts for the respiratory effect. The amount of carbon in a seaweed at a given time can be described as: $C_{j}=C_{i}+C_{\mathrm{p}}-C_{\mathrm{r}}$, where $C$ is carbon mass, $j$ and $i$ are 2 consecutive instants in time, $\mathrm{p}$ is photosynthesis and $\mathrm{r}$ is respiration. In order to simplify calculations, we are deliberately ignoring carbon loss through exudation or grazing. This is reasonable if it is assumed that the $\delta^{13} \mathrm{C}$ of the lost parts is similar to those that remain, which is probable for algae with small thalli, or if the losses are small, which is probably true for exudation in healthy algae (Carlson

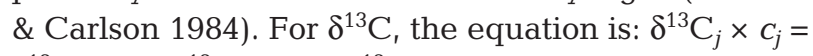
$\delta^{13} C_{i} \times C_{i}+\delta^{13} C_{\mathrm{p}} \times C_{\mathrm{p}}-\delta^{13} \mathrm{C}_{\mathrm{r}} \times C_{\mathrm{r}}$.

$\Delta_{\mathrm{p}}$ is defined as the difference between DIC $\delta^{13} \mathrm{C}$ and plant $\delta^{13} \mathrm{C}$. Assuming an isotopic steady state in the organism (reasonable if the biomass is high relative to gas exchange rates), it is possible to state that $\delta^{13} C_{j}=\delta^{13} C_{i}=\delta^{13} C_{a}$ (the $\delta^{13} C$ in the alga). We can define $C_{\mathrm{p}}$ as a multiple of $\mathrm{C}_{\mathrm{r}}$ by stating that $C_{\mathrm{p}}=\theta \times C_{\mathrm{r}}$ (where $\theta$ is the ratio $C_{\mathrm{p}} / C_{\mathrm{r}}$ ), and define $\delta^{13} \mathrm{C}_{\mathrm{r}}$ as a function of $\delta^{13} \mathrm{C}_{\mathrm{a}}$ as $\delta^{13} \mathrm{C}_{r}=\delta^{13} \mathrm{C}_{\mathrm{a}}+\Delta_{\mathrm{r}}$. After some simple algebra, we can rewrite the isotopic mass balance as: $\delta^{13} \mathrm{C}_{p}=\delta^{13} \mathrm{C}_{\mathrm{a}}+\Delta_{\mathrm{r}} / \theta$.

Here we found that $\Delta_{\mathrm{r}}=3 \%$ and the literature suggests a value of 2 for $\theta$ in seaweeds (Duarte \& Cebrian 1996, Middelburg et al. 2005). Therefore, $\delta^{13} \mathrm{C}_{\mathrm{a}}$ can be estimated as being $1.5 \%$ higher than $\delta^{13} \mathrm{C}_{\mathrm{p}}$. If this effect is valid for seaweeds in general, the limits indicating $\mathrm{HCO}_{3}{ }^{-}$and $\mathrm{CO}_{2}$ use for these organisms (Maberly et al. 1992, Raven et al. 2002) would need to be shifted slightly. In other words, a seaweed with $\delta^{13} \mathrm{C}_{\mathrm{a}}=-11.5 \%$ would be classified as able to use $\mathrm{HCO}_{3}^{-}$; based on the criteria of Maberly et al. (1992), it would be classified as such only if the value was $>-10 \%$. At the other extreme, another alga with a $\delta^{13} \mathrm{C}_{\mathrm{a}}$ value of $-31 \%$ would not be a $100 \% \mathrm{CO}_{2}$ only user (in Maberly et al. 1992 or Raven et al. 2002, any seaweed with a $\delta^{13} \mathrm{C}_{\mathrm{a}}$ value $<-30 \%$ would be so classified). Using this modified criterion for the specimens utilized in this study, we find that 8 Ulva sp. and 7 Sargassum sp. thalli would have likely actively taken up $\mathrm{HCO}_{3}{ }^{-}$in their photosynthesis in the natural ecosystem (Appendix 1). Of course, flexibility is needed when addressing these issues, as all parameters, notably $\Delta_{\mathrm{r}}$ and $\theta$, are subject to variation.

Acknowledgements. We thank S. Dworjanyn for helping with species identification, J. Oakes for reviewing the manuscript, and I. Alexander for doing nutrient analysis. This project was supported by an Australian Research Council (ARC) Discovery grant (DP0878683) and an ARC Linkage Infrastructure, Equipment and Facilities grant (LE0668495) awarded to B.D.E.

\section{LITERATURE CITED}

Bade DL, Carpenter SR, Cole JJ, Hanson PC, Hesslein RH (2004) Controls of $\delta^{13} \mathrm{C}$-DIC in lakes: geochemistry, lake metabolism, and morphometry. Limnol Oceanogr 49: 1160-1172

Barbour MM, McDowell NG, Tcherkez G, Bickford CP, Hanson DT (2007) A new measurement technique reveals rapid post-illumination changes in the carbon isotope composition of leaf-respired $\mathrm{CO}_{2}$. Plant Cell Environ 30: 469-482

Beardall J, Burger-Wiersma T, Rijkeboer M, Sukenik A, Lemoalle J, Dubinsky Z, Fontvielle D (1994) Studies on enhanced post-illumination respiration in microalgae. J Plankton Res 16:1401-1410

BoM (2011) Australian climate variability \& changeaverage maps. www.bom.gov.au/cgi-bin/climate/change/ averagemaps.cgi? $\mathrm{map}=$ sst\&season $=0112$

Bowling DR, Pataki DE, Randerson JT (2008) Carbon isotopes in terrestrial ecosystem pools and $\mathrm{CO}_{2}$ fluxes. New Phytol 178:24-40

Carlson DJ, Carlson ML (1984) Reassessment of exudation by fucoid macroalgae. Limnol Oceanogr 29:1077-1087

Carvalho MC, Hayashizaki K, Ogawa H (2009a) Carbon stable isotope discrimination: a possible growth index for the kelp Undaria pinnatifida. Mar Ecol Prog Ser 381: 71-82

Carvalho MC, Hayashizaki K, Ogawa H (2009b) Short-term measurement of carbon stable isotope discrimination in photosynthesis and respiration by aquatic macrophytes, with marine macroalgal examples. J Phycol 45:761-770

Carvalho MC, Hayashizaki K, Ogawa H (2010) Temperature effect on carbon isotopic discrimination by Undaria pinnatifida (Phaeophyta) in a closed experimental system. 
J Phycol 46:1180-1186

Del Giorgio PA, Williams PJIB (eds) (2005) Respiration in aquatic ecosystems. Oxford University Press, New York, NY

Dromgoole FI (1978) The effects of pH and inorganic carbon in photosynthesis and dark respiration of Carpophyllum (Fucales, Phaeophyceae). Aquat Bot 4:11-22

Duarte CM, Cebrian J (1996) The fate of marine autotrophic production. Limnol Oceanogr 41:1758-1766

Duranceau M, Ghashghaie J, Badeck F, Deleens E, Cornic G (1999) $\delta^{13} \mathrm{C}$ of $\mathrm{CO}_{2}$ respired in the dark in relation to $\delta^{13} \mathrm{C}$ of leaf carbohydrates in Phaseolus vulgaris L. under progressive drought. Plant Cell Environ 22:515-523

Enríquez S, Duarte CM, Sand-Jensen K, Nielsen SL (1996) Broad-scale comparison of photosynthetic rates across phototrophic organisms. Oecologia 108:197-206

Eyre BD, Ferguson AJP (2005) Benthic metabolism and nitrogen cycling in a sub-tropical east Australian estuary (Brunswick): temporal variability and controlling factors. Limnol Oceanogr 50:81-90

Eyre BD, Maher D (2010) Structure and function of warm temperate east Australian coastal lagoons: implications for natural and anthropogenic change. In: Kennish MJ, Paerl HW (eds) Coastal lagoons: critical habitats for environmental changes. CRC Press, Boca Raton, FL, p 457-481

Falkowski PG, Raven JA (2007) Aquatic photosynthesis. Princeton University Press, NJ

Falkowski PG, Dubinsky Z, Santostefano G (1985) Lightenhanced dark respiration in phytoplankton. Verh Internat Verein Limnol 22:2830-2833

Fenton GE, Ritz DA (1989) Spatial variability of ${ }^{13} \mathrm{C}:{ }^{12} \mathrm{C}$ and $\mathrm{D}: \mathrm{H}$ in Ecklonia radiata (C. Ag.) J. Agardh (Laminariales). Estuar Coast Shelf Sci 28:95-101

Finlay JC (2004) Patterns and controls of lotic algal stable carbon isotope ratios. Limnol Oceanogr 49:850-861

Fredriksen S (2003) Food web studies in a Norwegian kelp forest based on stable isotope $\left(\delta^{13} \mathrm{C}\right.$ and $\left.\delta^{15} \mathrm{~N}\right)$ analysis. Mar Ecol Prog Ser 260:71-81

Gessler A, Tcherkez G, Karyanto O, Keitel C and others (2009) On the metabolic origin of the carbon isotope composition of $\mathrm{CO}_{2}$ evolved from darkened light-acclimated leaves in Ricinus communis. New Phytol 181:374-386

Ghashghaie J, Badeck FW, Laningan G, Nogues S and others (2003) Carbon isotope fractionation during dark respiration and photorespiration in $\mathrm{C}_{3}$ plants. Phytochem Rev 2:145-161

Kroopnick PM (1985) The distribution of ${ }^{13} \mathrm{C}$ of $\Sigma \mathrm{CO}_{2}$ in the world ocean. Deep-Sea Res 32:57-84

Maberly SC, Raven JA, Johnston AM (1992) Discrimination between ${ }^{12} \mathrm{C}$ and ${ }^{13} \mathrm{C}$ by marine plants. Oecologia 91 : 481-492

Maher D, Eyre BD (in press) Benthic metabolism and carbon budgets in three geomorphologically distinct south east Australian estuaries. Mar Ecol Prog Ser doi:10.3354/ meps09336

Mercado JM, de los Santos CB, Pérez-Lloréns JL, Vergara JJ (2009) Carbon isotopic fractionation in macroalgae from Cádiz Bay (Southern Spain): comparison with other biogeographic regions. Estuar Coast Shelf Sci 85:449-458

Middelburg JJ, Duarte CM, Gattuso JP (2005) Respiration in coastal benthic communities. In: Del Giorgio PA, Williams PJIB (eds) Respiration in aquatic ecosystems. Oxford University Press, New York, NY, p 206-224

Oakes JM, Eyre BD, Ross DJ, Turner SD (2010) Stable isotopes trace estuarine transformations of carbon and nitrogen from primary- and secondary-treated paper and pulp mill effluent. Environ Sci Technol 44:7411-7417

Park R, Epstein S (1961) Metabolic fractionation of $\mathrm{C}^{13}$ and
$\mathrm{C}^{12}$ in plants. Plant Physiol 36:133-138

Pataki DE (2005) Emerging topics in stable isotope ecology: are there isotope effects in plant respiration? New Phytol 167:321-323

Pringault O, Tassas V, Rochelle-Newall E (2007) Consequences of respiration in the light on the determination of production in pelagic systems. Biogeosciences 4: 105-114

Raven JA, Geider RJ (1988) Temperature and algal growth. New Phytol 110:441-461

Raven JA, Beardall J, Griffiths H (1982) Inorganic C-sources for Lemanea, Cladophora, and Ranunculus in a fastflowing stream: measurements of gas exchange and of carbon isotope ratio and their ecological implications. Oecologia 53:68-78

Raven JA, Johnston AM, Newman JR, Scrimgeour CM (1994) Inorganic carbon acquisition by aquatic photolithotrophs of the Dighty Burn, Angus, UK: uses and limitations of natural abundance measurements of carbon isotopes. New Phytol 127:271-286

Raven JA, Johnston AM, Kübler JE, Korb R and others (2002) Mechanistic interpretation of carbon isotope discrimination by marine macroalgae and seagrasses. Funct Plant Biol 29:355-378

Sand-Jensen K, Nielsen SL (2004) Estuarine primary producers. In: Nielsen SL, Banta GT, Pedersen MF (eds) Estuarine nutrient cycling: the influence of primary producers. The fate of nutrients and biomass. Kluwer Academic Publishing, Dordrecht, p 17-57

Stephenson RL, Tan FC, Mann KH (1984) Stable carbon isotope variability in marine macrophytes and its implications for food web studies. Mar Biol 81:223-230

Tcherkez G, Nogues S, Bleton J, Cornic G, Badeck F, Ghashghaie J (2003) Metabolic origin of carbon isotope composition of leaf dark-respired $\mathrm{CO}_{2}$ in French bean. Plant Physiol 131:237-244

Tcherkez G, Schäufele R, Nogués S, Piel C and others (2010) On the ${ }^{13} \mathrm{C} /{ }^{12} \mathrm{C}$ isotopic signal of day and night respiration at the mesocosm level. Plant Cell Environ 33:900-913

Valiela I, McClelland J, Hauxwell J, Behr PJ, Hersh D, Foreman K (1997) Macroalgal blooms in shallow estuaries: controls and ecophysiological and ecosystem consequences. Limnol Oceanogr 42:1105-1118

Weger HG, Herzig R, Falkowski PG, Turpin DH (1989) Respiratory losses in the light in a marine diatom: measurements by short-term mass spectrometry. Limnol Oceanogr 34:1153-1161

Werner C, Hasenbein N, Maia R, Beyschlag W, Máguas C (2007) Evaluating high time-resolved changes in carbon isotope ratio of respired $\mathrm{CO}_{2}$ by a rapid in-tube incubation technique. Rapid Commun Mass Spectrom 21: $1352-1360$

Werner C, Wegener F, Unger S, Nogués S, Priault P (2009) Short-term dynamics of isotopic composition of leafrespired $\mathrm{CO}_{2}$ upon darkening: measurements and implications. Rapid Commun Mass Spectrom 23:2428-2438

Wiencke C, Fischer G (1990) Growth and stable carbon isotope composition of cold-water macroalgae in relation to light and temperature. Mar Ecol Prog Ser 65:283-292

Won NI, Kawamura T, Onistsuka T, Hayakawa J and others (2007) Community and trophic structures of abalone Haliotis diversicolor habitat in Sagami Bay, Japan. Fish Sci 73:1123-1136

Zeebe RE, Wolf-Gladrow D (2001) $\mathrm{CO}_{2}$ in seawater: equilibrium, kinetics, isotopes. Elsevier, Amsterdam

Zou D, Gao K (2010) Acquisition of inorganic carbon by Endarachne binghamiae (Scytosiphonales, Phaeophyceae). Eur J Phycol 45:117-126 


\section{Appendix 1}

Full list of results for the incubations. Time: incubation time (min); Vol: incubation water volume (ml); $\mathrm{O}_{2}$ : dissolved oxygen concentration $\left(\mathrm{mg} \mathrm{l}^{-1}\right)$; [DIC]: dissolved inorganic carbon concentration $\left(\mathrm{mmol} \mathrm{l}^{-1}\right) ; \delta^{13} \mathrm{C}$ : stable carbon isotope composition $(\%)$; DW: dry weight $(\mathrm{g})$ of the alga used in the incubation; \% Org C: \% of organic carbon in the alga used in the incubation; ${ }_{\mathrm{s}}$ : start of the incubation; e $_{\text {: end of the incubation }}$ p: plant; 15L, 25L and 25D: refer to Fig. 1

\begin{tabular}{|c|c|c|c|c|c|c|c|c|c|c|c|}
\hline & Time & Vol & $\mathrm{O}_{2 \mathrm{~s}}$ & $\mathrm{O}_{2 \mathrm{e}}$ & {$[\mathrm{DIC}]_{\mathrm{s}}$} & {$[\mathrm{DIC}]_{\mathrm{e}}$} & $\delta^{13} \mathrm{C}_{\mathrm{s}}$ & $\delta^{13} \mathrm{C}_{\mathrm{e}}$ & DW & $\%$ Org C & $\delta^{13} C_{p}$ \\
\hline \multicolumn{12}{|c|}{ Ulva sp. } \\
\hline \multirow[t]{7}{*}{$15 \mathrm{~L}$} & 54 & 25 & 9.50 & 5.58 & 0.18 & 0.31 & -6.0 & -4.6 & 0.159 & 26.7 & -11.0 \\
\hline & 51 & 20 & 9.33 & 5.16 & 0.18 & 0.32 & -4.8 & -6.4 & 0.213 & 31.4 & -12.3 \\
\hline & 27 & 24 & 9.49 & 7.44 & 0.18 & 0.30 & -5.5 & -5.5 & 0.205 & 31.6 & -14.2 \\
\hline & 56 & 28 & 9.53 & 4.06 & 0.18 & 0.36 & -6.8 & -8.2 & 0.392 & 30.6 & -11.4 \\
\hline & 30 & 22 & 9.55 & 4.04 & 0.19 & 0.31 & -6.9 & -6.8 & 0.177 & 30.2 & -12.7 \\
\hline & 29 & 22 & 9.52 & 4.16 & 0.18 & 0.28 & -6.9 & -7.1 & 0.211 & 30.5 & -12.5 \\
\hline & 58 & 25 & 9.50 & 2.74 & 0.19 & 0.30 & -6.8 & -6.3 & 0.211 & 29.6 & -14.0 \\
\hline \multirow[t]{7}{*}{$25 \mathrm{~L}$} & 33 & 21 & 8.25 & 2.77 & 0.18 & 0.33 & -6.5 & -7.3 & 0.137 & 31.4 & -13.1 \\
\hline & 16 & 26 & 7.80 & 2.28 & 0.19 & 0.30 & -7.1 & -6.5 & 0.213 & 31.4 & -11.2 \\
\hline & 27 & 25 & 8.26 & 2.33 & 0.18 & 0.30 & -7.8 & -8.0 & 0.141 & 30.3 & -10.9 \\
\hline & 24 & 25 & 8.29 & 1.68 & 0.18 & 0.30 & -7.9 & -7.7 & 0.194 & 28.3 & -11.3 \\
\hline & 43 & 24 & 8.35 & 3.13 & 0.18 & 0.28 & -7.5 & -8.8 & 0.106 & 31.2 & -13.1 \\
\hline & 59 & 25 & 8.22 & 2.95 & 0.20 & 0.29 & -7.9 & -8.4 & 0.109 & 28.3 & -12.5 \\
\hline & 64 & 24 & 8.33 & 3.03 & 0.19 & 0.30 & -8.6 & -8.4 & 0.091 & 29.3 & -12.9 \\
\hline \multirow[t]{6}{*}{$25 \mathrm{D}$} & 41 & 25 & 8.29 & 3.81 & 0.19 & 0.27 & -8.0 & -8.3 & 0.124 & 29.2 & -10.9 \\
\hline & 45 & 25 & 8.10 & 2.27 & 0.25 & 0.34 & -4.5 & -7.7 & 0.126 & 30.3 & -10.9 \\
\hline & 38 & 23 & 8.12 & 3.21 & 0.21 & 0.30 & -4.8 & -7.9 & 0.187 & 28.2 & -13.4 \\
\hline & 27 & 23 & 8.26 & 3.24 & 0.22 & 0.33 & -4.3 & -7.9 & 0.135 & 23.8 & -13.1 \\
\hline & 38 & 23 & 8.99 & 3.21 & 0.20 & 0.33 & -5.0 & -7.6 & 0.194 & 29.1 & -13.6 \\
\hline & 41 & 20 & 9.04 & 2.57 & 0.23 & 0.34 & -4.3 & -6.9 & 0.130 & 29.8 & -10.1 \\
\hline \multicolumn{12}{|c|}{ Pterocladia capillacea } \\
\hline \multirow{7}{*}{$15 \mathrm{~L}$} & 64 & 19 & 9.62 & 7.55 & 0.38 & 0.46 & 1.5 & -0.2 & 0.116 & 36.0 & -14.9 \\
\hline & 44 & 19 & 9.61 & 6.84 & 0.39 & 0.52 & 0.7 & -2.1 & 0.195 & 35.5 & -14.1 \\
\hline & 64 & 21 & 9.54 & 7.23 & 0.40 & 0.46 & 0.5 & -1.5 & 0.182 & 35.6 & -15.7 \\
\hline & 57 & 21 & 9.67 & 6.52 & 0.40 & 0.53 & 0.1 & -2.4 & 0.207 & 35.1 & -13.5 \\
\hline & 36 & 20 & 9.67 & 7.07 & 0.40 & 0.51 & 0.3 & -2.0 & 0.197 & 36.9 & -14.4 \\
\hline & 39 & 22 & 9.69 & 6.41 & 0.40 & 0.49 & 0.3 & -1.9 & 0.263 & 35.2 & -14.0 \\
\hline & 86 & 22 & 9.69 & 7.05 & 0.40 & 0.51 & -0.3 & -2.6 & 0.267 & 32.9 & -14.9 \\
\hline \multirow[t]{6}{*}{$25 \mathrm{~L}$} & 42 & 20 & 8.62 & 5.40 & 0.40 & 0.47 & 0.5 & -1.9 & 0.132 & 35.7 & -15.0 \\
\hline & 51 & 20 & 8.51 & 4.55 & 0.39 & 0.50 & 0.2 & -2.8 & 0.136 & 35.8 & -15.0 \\
\hline & 60 & 22 & 8.58 & 3.24 & 0.38 & 0.59 & -0.4 & -4.4 & 0.303 & 34.0 & -15.6 \\
\hline & 48 & 21 & 8.47 & 3.09 & 0.39 & 0.52 & -0.5 & -3.5 & 0.147 & 36.3 & -15.6 \\
\hline & 41 & 21 & 8.51 & 3.65 & 0.38 & 0.50 & -0.5 & -3.4 & 0.175 & 28.3 & -15.1 \\
\hline & 46 & 21 & 8.41 & 5.67 & 0.39 & 0.45 & -0.7 & -2.5 & 0.131 & 30.5 & -15.9 \\
\hline \multirow[t]{7}{*}{$25 \mathrm{D}$} & 54 & 21 & 8.57 & 4.94 & 0.39 & 0.52 & -1.0 & -3.8 & 0.268 & 35.3 & -16.3 \\
\hline & 55 & 12 & 8.35 & 2.83 & 0.40 & 0.56 & -0.9 & -4.6 & 0.210 & 35.6 & -14.4 \\
\hline & 65 & 12 & 8.45 & 4.17 & 0.39 & 0.49 & -1.3 & -3.5 & 0.196 & 36.6 & -15.6 \\
\hline & 43 & 12 & 8.30 & 2.89 & 0.41 & 0.52 & -1.7 & -3.6 & 0.327 & 37.1 & -14.7 \\
\hline & 43 & 12 & 8.30 & 3.60 & 0.40 & 0.50 & -0.9 & -3.4 & 0.292 & 35.4 & -15.6 \\
\hline & 54 & 12 & 8.24 & 3.48 & 0.38 & 0.50 & -1.0 & -3.6 & 0.219 & 34.4 & -16.3 \\
\hline & 52 & 23 & 8.34 & 1.54 & 0.38 & 0.56 & -1.1 & -4.5 & 0.339 & 35.0 & -15.6 \\
\hline \multicolumn{12}{|c|}{ Sargassum sp. } \\
\hline \multirow{6}{*}{$15 \mathrm{~L}$} & 61 & 24 & 9.43 & 6.57 & 0.54 & 0.62 & 5.0 & 3.5 & 0.201 & 28.7 & -10.2 \\
\hline & 57 & 21 & 9.61 & 5.08 & 0.52 & 0.68 & 4.1 & 2.1 & 0.377 & 30.0 & -12.8 \\
\hline & 50 & 22 & 9.45 & 7.07 & 0.51 & 0.63 & 3.6 & 2.0 & 0.202 & 31.2 & -13.1 \\
\hline & 69 & 23 & 9.63 & 7.53 & 0.52 & 0.62 & 3.1 & 1.9 & 0.189 & 27.4 & -14.4 \\
\hline & 57 & 23 & 9.68 & 5.19 & 0.52 & 0.68 & 2.4 & -0.4 & 0.245 & 29.3 & -16.3 \\
\hline & 36 & 23 & 9.65 & 6.99 & 0.56 & 0.65 & 2.0 & 0.4 & 0.229 & 27.9 & -10.0 \\
\hline \multirow[t]{5}{*}{$25 \mathrm{~L}$} & 63 & 20 & 8.52 & 4.10 & 0.55 & 0.64 & 2.3 & 0.1 & 0.113 & 29.5 & -13.2 \\
\hline & 60 & 21 & 8.47 & 4.03 & 0.54 & 0.66 & 1.9 & 0.1 & 0.156 & 26.1 & -11.5 \\
\hline & 66 & 22 & 8.53 & 4.20 & 0.54 & 0.65 & 1.2 & -0.4 & 0.181 & 29.8 & -13.9 \\
\hline & 52 & 22 & 8.46 & 3.96 & 0.54 & 0.64 & 0.9 & -1.1 & 0.265 & 28.4 & -14.3 \\
\hline & 38 & 22 & 8.49 & 4.16 & 0.55 & 0.64 & 0.7 & -1.2 & 0.309 & 29.6 & -14.5 \\
\hline \multirow[t]{5}{*}{$25 \mathrm{D}$} & 40 & 21 & 8.48 & 5.25 & 0.55 & 0.61 & 1.1 & -0.3 & 0.283 & 25.4 & -11.5 \\
\hline & 36 & 21 & 8.57 & 4.59 & 0.55 & 0.61 & 1.0 & -0.7 & 0.169 & 28.6 & -13.9 \\
\hline & 35 & 22 & 8.30 & 3.65 & 0.55 & 0.61 & 1.1 & -0.7 & 0.287 & 27.8 & -14.0 \\
\hline & 53 & 21 & 8.54 & 4.73 & 0.53 & 0.60 & 0.7 & -0.6 & 0.244 & 25.5 & -10.1 \\
\hline & 48 & 23 & 8.27 & 4.88 & 0.53 & 0.62 & 1.0 & -0.2 & 0.197 & 29.6 & -11.1 \\
\hline
\end{tabular}

